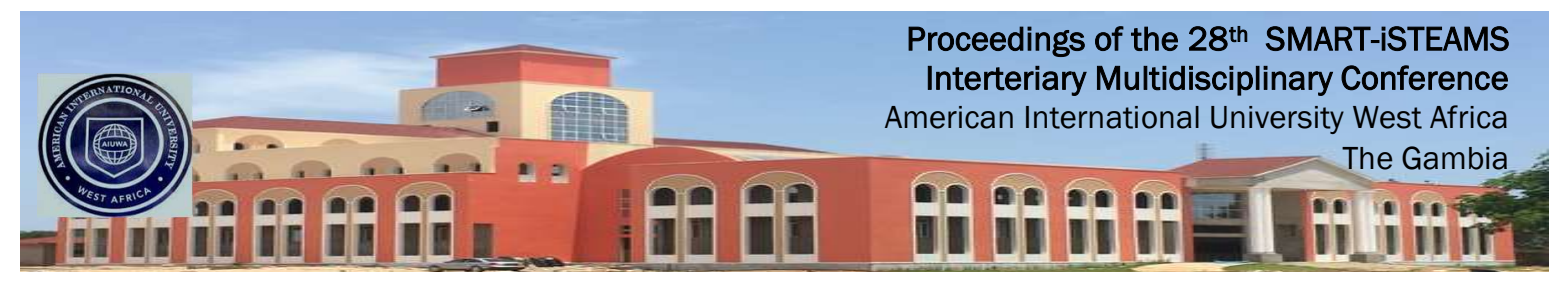

\author{
Full Research Paper
}

\title{
Comparative Study of Institutional Facilities as Predictors of Students Choice of Schools: Case Study of Public Tertiary Institutions in Lagos, Nigeria.
}

\section{SOKOYA, Abiola Abosede \\ Deputy Polytechnic Librarian \\ Yaba College of Technology \\ Yaba, Lagos State, Nigeria}

\section{YABATECH

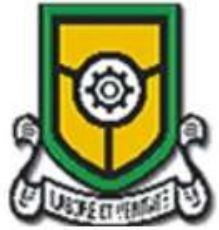

\section{Doctoral Research Student Dept of Library Studies University of Ibadan Ibadan, Nigeria}

\section{E-mails} aasokoya@yahoo.co.uk abiola.sokoya@yabatech.edu.ng

Phone No

$+2348023336632$

\begin{abstract}
Institutional facilities often determine students' choice of enrolment into tertiary institution and level of academic performance Rudhumbu,Tirumali and Kumari, (2017). Thus institutions invest more on installation and maintenance of facilities like business enterprise to compete favorably with their counterparts in order to have good number of students and to improve institutional image and status (Gibbs, 2001). Despite institutions stringent requirements of students' academic results from high school, parents are more concerned of institutional image; safety and campus security. This paper focused on institutional facilities as predictors of students' choice of enrolment into tertiary institutions for further studies. The study population comprised of year two students in all fields of study from each level of tertiary institutions (college of education, polytechnic and university) in Lagos, Nigeria. It also examined the impact of available facilities ranging from library facilities and services, internet facilities, campus accommodation and proximity to the library and lecture rooms, lecturers experience and academic qualifications are inclusive facilities examined in this study. The study also mirror on the admission requirements of the various schools under study, the structural facilities need of all categories of students in the study; the place of the physically challenged students inclusive. The study adopted survey designed research with the aid of both self structured questionnaire, observation and interview as research instruments for clarification. The services of research assistance hinged on the distribution and collation of questionnaires for the study. Statistical Package for the Social Sciences (SPSS) software was used to analyse the data. Conclusion and recommendations was drawn based on the research findings.
\end{abstract}

Keywords: Institutional facilities, library, students' enrolment.

Proceedings Reference Format

Sokoya, A.A. (2021): Comparative Study of Institutional Facilities as Predictors of Students Choice of Schools: Case Study of Public Tertiary Institutions in Lagos, Nigeria. Proceedings of the 28th iSTEAMS Intertertiary Multidisciplinary Conference. American International University West Africa, The Gambia. October, 2021. Pp 37-46 www.isteams.net/gambia2021.

DOI - https://doi.org/ 10.22624/AIMS/iSTEAMS-2021/V28P3 


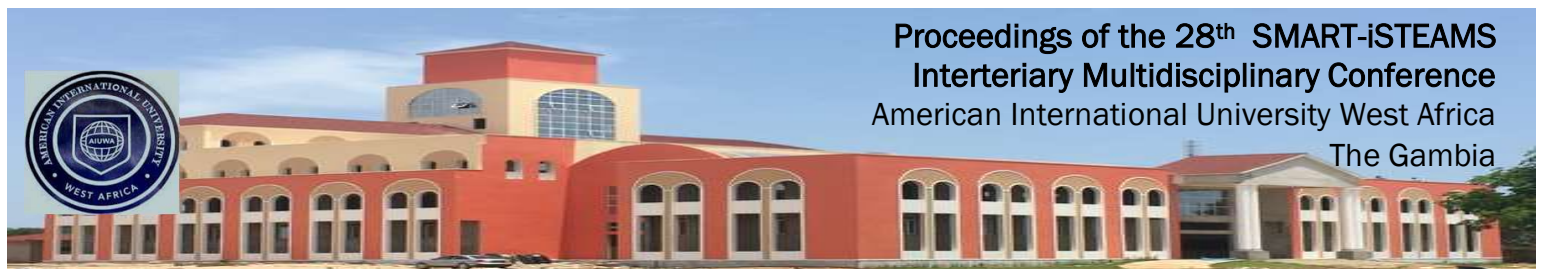

\section{INTRODUCTION}

Achievement as accomplished at the end of every exercise or endaevour is often measured by the level of success. Business ventures have mission and vision towards accomplishments, thus high school students could visualize the level of their desired attainment in academic pursuit due to passion and influence of certain factors. These factors could be of intrinsic and extrinsic influence; such as the level of another individual's life and achievements (mentors). The level of mentors' academic status could influence students desire to opt for career in academics and in a particular field of study including mentors' alma mater. Also, student could have the notion that available institutional facilities could be judgmental to academic achievement and societal recognition thereby placing value on such factors to facilitate choice. On this premise available facilities in tertiary institution could influence students' choice of option for enrolment for course of study in public tertiary institution in addition to high school grades.

These facilities could include institutional image; stability of academic calendar, entry requirements, campus security, on-campus accommodation, available courses of study, library support services; internet and e-resources among other infrastructures. According to Adeyemi, and Adeyemi, (2014), institutional facilities often determine students' choice of enrolment into tertiary institution and in addition to the level of academic performance. Thus institutions invest more on installation and maintenance of facilities like business enterprise to compete favorably with their counterparts so as to have good number of students' enrolment and to improve institutional image and status (Gibbs, 2001). Despite institutions stringent requirements of students' academic results from high school, parents' are more concerned of institutional image and campus security. This paper will focus on institutional facilities as predictors of students' choice of enrolment into public tertiary institution in Lagos Nigeria.

Admission into tertiary institutions posed a serious issue in Nigeria due to stringent rules and conditions from different quarters like the Federal Government admission policy on catchment area, examination bodies and low level of available number of public tertiary institutions to admit the teaming population of young adults. However, despite all odds, students do struggle to meet the criteria for admission due to their desire for higher education to make a better life. The big gap between students' large population for admission and the number of available public tertiary institution does not make students grovel for admission into unaccredited institutions with less facility for academic and social advancement. Thus qualified students do gun for tertiary institutions that have facilities that would academic excellence. However these institutional facilities could determine students' option for enrolment into tertiary.

\subsection{Study Aims and Objectives}

The study sought to address the following research objectives:

$>$ To identity the institutional facilities that predicts students choice of enrolment into public tertiary institutions in Lagos, Nigeria

$>$ To investigate the extent at which institution facilities predict students' choice of enrolment into public tertiary institutions in Lagos, Nigeria. 


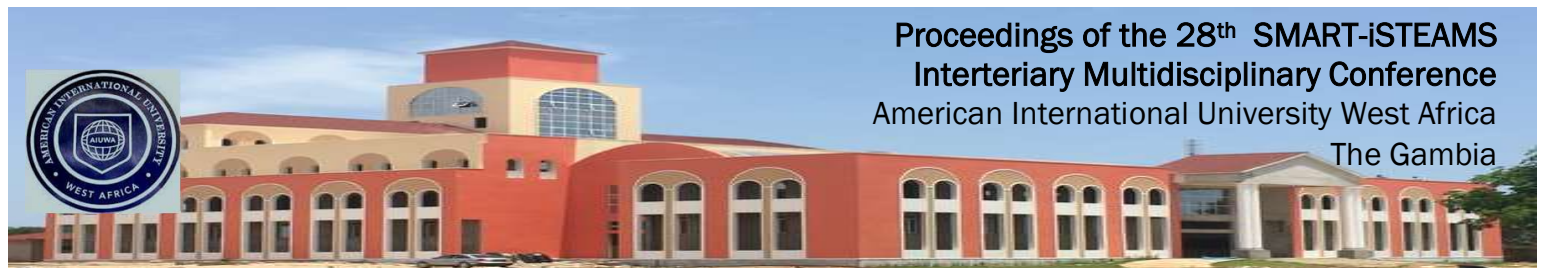

\subsection{Research Questions}

1. What are the institutional facilities that predict students' choice of enrolment into public tertiary institution in Lagos, Nigeria?

2. What are the major institutional facilities that affect students' choice of enrolment into public tertiary institution in Lagos, Nigeria?

3. What are the effects of institutional facilities on students' choice of enrolment into public tertiary institution in Lagos, Nigeria?

\section{LITERATURE REVIEW}

Admission into tertiary institutions pose to be serious issue in Nigeria due to stringent rules and conditions from different quarters like the Federal Government admission policy on catchment area, examination bodies / agencies and the available number of public tertiary institutions to admit the teaming population of young adults. However, despite all odds, students do struggle to meet the criteria for admission due to their desire for higher education to make a better life. The big gap between students' large population for admission and the number of available public tertiary institution does not make students grovel for admission into unaccredited institutions with less facility that could make for academic and social advancement. Thus qualified students always apply for tertiary institutions that have facilities for academic excellence. However these institutional facilities could determine students' option for enrolment into tertiary institution; thus this study look into some of these facilities.

These facilities are the major tools shaping the institutional image. Accordingly, institutional image could affect students' choice for enrolment. Miha, Jasmina and Marko (2010) survey among students in Slovenia shows institutional image as a major factor that determine students enrolment into tertiary institution. Also, Ademola, Ogundipe, and Babatunde (2014) study on students' enrolment into tertiary institution in Nigeria revealed that the image of the institution such as the founders' reputation in the society do influence students choice of enrolment into tertiary institution.

In addition, stability of academics calendar, retaining students' academic performance could predict new students' option for enrolment. As far as three decades back researchers (Ramist1971; Johnston ,1987; Ukeji, 1999) observed that students choice of enrolment into tertiary institution is a function of the image of the institution to the society; both in status, academic and management policies. Ramist et.al emphasised on the institutional image in line with management authority policies as key because of students' expectations on what the institution should offer as a reputable accredited institution to support their academic achievement in record time and to have a place in the society.

According to Dowen (2006), administrative and management policies on admission criteria could influence students choice for enrolment. Cruce and Moore, (2006) corroborate that students perception on institution image on admission requirements and campus setting do shape students choice and decision for enrolment. In addition, Johnston, (1997) research among students in the United Kingdom found out that policies and available facilities do influence students' enrolment decision. 


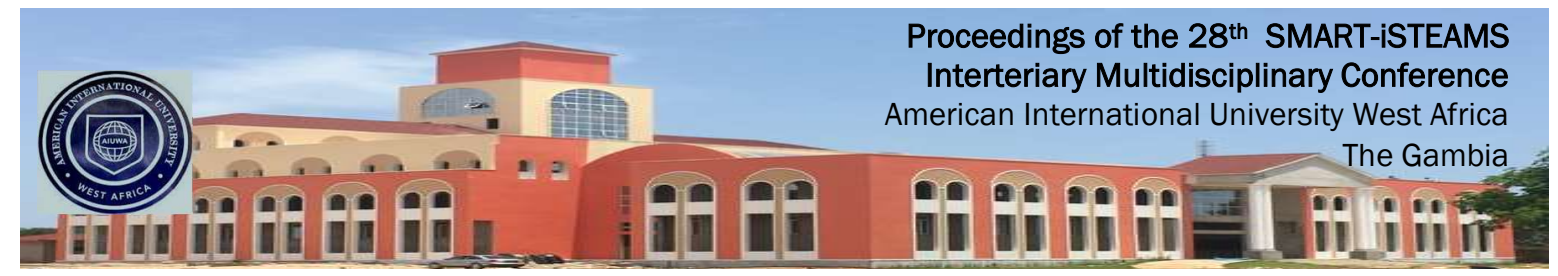

Availability of functional facilities such as easy access to institutional website with up to date information could influence students' choice to know available courses of study and entry requirements. To a large extent stable academic calendar as well as on campus accommodation are paramount factors on the list of students expected facilities for safety and excellent performance in tertiary institution. On this premise, (Uwadiae, 2000; Owusu-Agyeman, 2006; Adeyemi, 2014) reiterate that manpower is germane to academic performance, which could be part of students expectation in shaping their option for enrolment. Thus retaining students' experience of smooth running of academic programs could influence incoming students' enrolment. Kusumawati (2013) survey among Indonesia students reveals the quest for lecturers' status as one of the reasons for choice of enrolment in addition to suggestion and encouragement coming from family and friends.

In Malaysia, Wangerner and Ford (2009), reports lecturers' qualification as determining factor for students' enrolment. Howbeit, Luque- Mcertinez and Barrio (2008); Abbasi and Mir (2012) corroborate qualified manpower (lecturers' status) as predictor of students' enrolment opinion. Availability of recreational facilities for extra-curricular activities like sports, leisure is not left out of the determinant facilities influencing students' choice of enrolment (Kusumawati, 2013; Dawes and Brown 2000). Also, (Abimbola;2016; Abbasi and Mir, 2012) survey, reported standard library services facilities as support service for research, teaching and learning; that influence academic performance and in turn advertise institutional image positively for students enrolment option. However, Ekwelem, (2013) reports that disable students are not always considered in most tertiary institution. That there is no special admission policy, no inclusive library setting or service in most tertiary institutions.

On this premise, Baniro and Adedgi (2010) opine on physical facilities such as library setting and services as predictors of students' choice of enrolment into tertiary institution, in line with UNESCO (2012) declaration for functional infrastructures such as standard library facilities among the listed facilities that must be provided in tertiary institutions to boost academic performance.

Accordingly, researches reveal that different facilities do influence students enrolment; these are on-campus accommodation among Nigerian students, Azeez, Taiwo, Mogaji-Alison and Bello (2016), while (Arpan et.al 2003; Miha et al 2010) survey show conducive campus environment as expected facilities that could enhance students' enrolment. In the same vein, Chaudhry, Shafiqs and Barhanu (2011) corroborated conducive campus environment and functional infrastructure that are key to students' choice of enrolment. In addition, (Kazaleas , 2001; Qwusu-Agyeman,2006; and Cheryll,2000) point out the need for on-campus accommodation as another predictor of challenged students option for enrolment into tertiary institution both in Cape Town and Canada respectively.

However, not all intending students could participate in the use of sporty facilities because of their diverse physical challenges which could be inimical to their choice for enrolment. On this premise, Cherll (2000) support the fact that students with disabilities need institutional support to enable them have equal opportunities for easy access to education. This is in line with UNICEF (2012) declaration for equal opportunity for disable people that are much inclined to embrace and advance in their quest for higher education. 


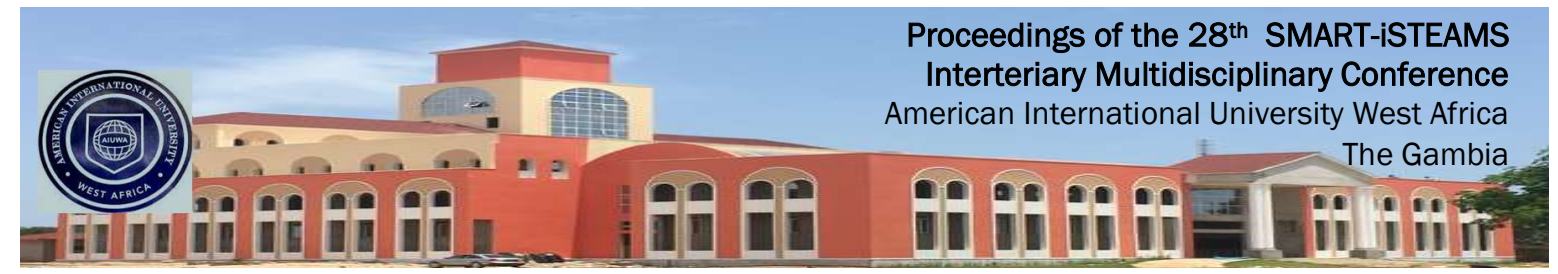

On this premise this study look into the place of disable student (herewith referred as challenged students) in tertiary institution policies; admission requirements, administrative issues, on-campus infrastructures; such as suitable accommodation, location of hostel accommodation to lecture rooms and the library as it may predict challenged students choice of enrolment.

At the United Nations convention in 2006, and 2012 convention, the right of people with disabilities were dwelt upon to make for equal recognition of their human rights to enable them receive necessary effective educational support as human being. However, it is believed that these categories of people are misunderstood by their body limitations. Accordingly, Louise and Alison, (2011) support UNESCO declaration; that challenged students are only having constraints, limitations of certain parts of their body, thereby reduces movement but not negating their desire for further education for improved status as human being. Kallio(1995) deliberate on institutional facilities that could influence the choice and decision of challenged students enrolment into tertiary institution.

As a matter of preference, emphases were laid on the campus environmental issues and geographical location for challenged students to enjoy available facilities thereby could reduce the pain of limitations in movement. The importance of suitable architectural designs of physical facilities such as hall of resident and inclusion of campus social life, college activities (Louse, 2011; Chataika, 2010; Thomas and Patricia 2004; Kallio1995) are additional factors that could induce enrolment option of challenged students. In Nigeria, (Adeyemi et.al; Arpan, 2003; Kanyip 2013) survey show that admission requirement is the same criteria for all categories of students.

\section{METHODOLOGY}

The study adopted survey designed research with the aid of both self structured questionnaire, observation and interview as research instruments for clarification. Observation and interview as research instruments were adopted to enable challenged students participate on their own free will. Therefore, students were randomly selected at different locations such as the library and students' shopping centers and saloon by the researcher. Research assistance was engaged for the distribution and collation of questionnaires from the different three sampled tertiary institutions for the study.

One Hundred and twenty (120) questionnaires were administered while one hundred and eighty (108) was retrieved back and found useful for data analysis with a response rate of $90 \%$ as found adequate for analysis based on Alreck and Settle (1985) submission that proposed 10\%. Statistical Package for the Social Sciences (SPSS) software was used to analyse the data collected. 


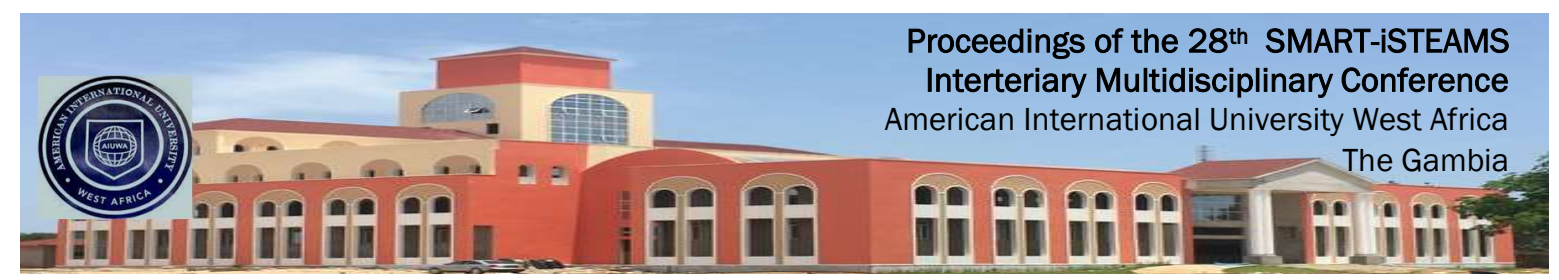

\section{DATA ANALYSIS AND PRESENTATION}

Data collected were collated and put to reliability test, the report shows a high correlation value of 0.972 , which translate that the instrument was reliable.

Table 1. Type of tertiary institution sampled

\begin{tabular}{|c|r|r|r|r|}
\hline Tertiary institution & Frequency & Percentage & \multicolumn{1}{|c|}{$\begin{array}{c}\text { Valid } \\
\text { Percent }\end{array}$} & Cumulative Percent \\
\hline College of & 36 & 33.3 & 33.3 & 33.3 \\
education & 37 & 34.3 & 34.3 & 67.6 \\
Polytechnic & 35 & 32.4 & 32.4 & 100.0 \\
University & 108 & 100.0 & 100.0 & \\
Total & & & \\
\hline
\end{tabular}

The above table shows all the three arms of tertiary institutions that were randomly sampled and well representing public tertiary institutions in Lagos. In this, 36 (33\%) students of the respondents were from college of education, while 37 (34\%) of the respondents were polytechnic students and $35(32 \%)$ of the respondents were from the university making a total $100 \%$ of respondents from the (3) three arms of tertiary institutions that are selected in Lagos State, Nigeria for the study. Also a large number of the disable students that participated in this study were university students that were met in the special creative space in the library; a special unit of the library with special facilities and structures suitable for the need of the disable students.

However, the case is different in the colleges of education because disable students are more catered for by the Federal Government in "college of education special". That is the Federal Government of Nigeria do have special concern for all disable students that would like to continue their education in tertiary institution in Nigeria. On this premise, college of education special is established specifically for disabled students to be admitted with special admission criteria at "College of Education Special" in Oyo State, Nigeria. College of Education Special has special facilities for all categorises of limitations of the disable students. The college also run both technical and vocational course of study to engage the students better and prepare them for the society.

Though the institution is fulfilling UNESCO (2006) laid down rule of education for all categories of people, it is also creating platform for training the tanners, to continue the trend of training disable individuals to have their place in the society for a better tomorrow. Accordingly two respondents among the disable students believed that establishment of special college of education for disable students and the available facilities is a move by the Federal Government of Nigeria to getting more qualified trained teachers that could teach disable people who are ready to advance in their desire for higher education. In the polytechnic, 37 (34\%) are among the total respondents in this study, however, 5(7.1\%) among these respondents are disable students who professed that their admission was as those of the regular students without any special concession on their physical conditions. 


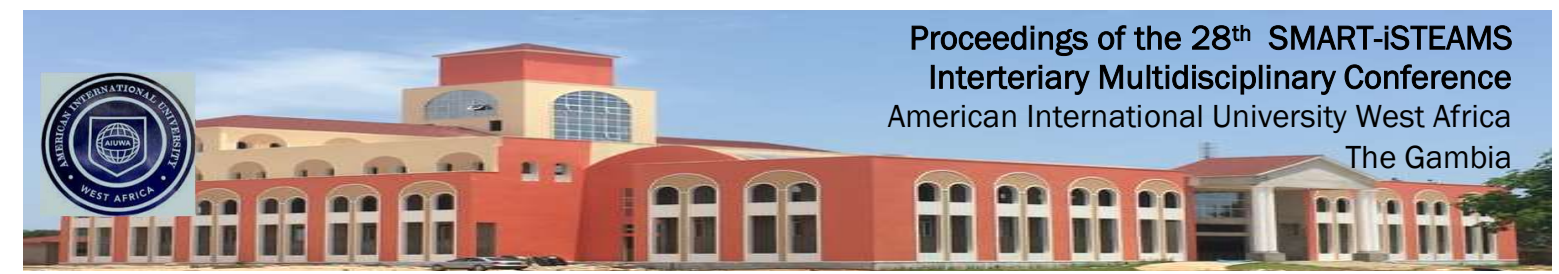

The polytechnic sampled has a unit specially carved out in the library for the disable students with two library staff to assist them in their need to use library resources. However, admission policy of the institution does not specify special criteria for these categories of students. Admission requirements for disable students are as that of the regular students, but the polytechnic gives special concession to disabled student where such students' identity is revealed to the authority. However, they professed to have chosen to enrol in these institutions for the available facilities; institutional website and image.

Although respondents in the university sampled has special unit in the main library with library staff that help disable students on their instructional needs, computer programme and also as guide to get regular students that will lead the individual disabled students to lecture rooms. According to some of the disable students respondents, having a unit of their own is encouraging their use of the available institutional facilities. Also, this act enable disable students to come together and make a formidable group by relating with one another; give them the opportunity to exchange ideas to surmount some challenges especially for their comfort and making headway in their studies. However, respondents among regular students in the university attested that campus security is the major option for their choice for enrolment, followed by the availability of their course of choice of study.

Table 2: Available institutional facilities for students' enrolment options

\begin{tabular}{|l|l|l|l|l|l|}
\hline S/N & INSTITUTIONAL FACILITIES & Agree & Disagree & Mean & \\
\hline 1 & $\begin{array}{l}\text { Available information on Institutional } \\
\text { website }\end{array}$ & $81 \%$ & $19 \%$ & $5^{\text {th }}$ & \\
\hline 2 & Institutions' bill board & $88 \%$ & $22 \%$ & $3^{\text {rd }}$ & \\
\hline 3 & Sport and sports complex/arena & $75 \%$ & $25 \%$ & $9^{\text {th }}$ & \\
\hline 4 & Functional facilities for disable students & $54 \%$ & $46 \%$ & $12^{\text {th }}$ & \\
\hline 5 & Campus accommodation & $79 \%$ & $21 \%$ & $7^{\text {th }}$ & \\
\hline 6 & Library facilities & $85 \%$ & $15 \%$ & $4^{\text {th }}$ & \\
\hline 7 & Free wifi & $76 \%$ & $24 \%$ & $8^{\text {th }}$ & \\
\hline 8 & Campus security & $91 \%$ & $09 \%$ & $1^{\text {st }}$ & \\
\hline 9 & Safe environment & $90 \%$ & $10 \%$ & $2^{\text {nd }}$ & \\
\hline 10 & Standard lecture rooms & $80 \%$ & $20 \%$ & $6^{\text {th }}$ & \\
\hline 11 & Conducive campus shuttle & $66 \%$ & $34 \%$ & $11^{\text {th }}$ & \\
\hline 12 & Students shopping mail/ centre & $68 \%$ & $32 \%$ & $10^{\text {th }}$ & \\
\hline & Overall Weighted Mean & & & & 3.9 \\
\hline
\end{tabular}

The table above shows that institutional facilities are well represented in public tertiary institutions in Lagos, Nigeria. However, $91 \%$ of the respondents agreed to campus security as of major concern for their enrolment option. This is followed by safety of the environment; the community where the institution is situated shows of good guide for students' option for enrolment. 


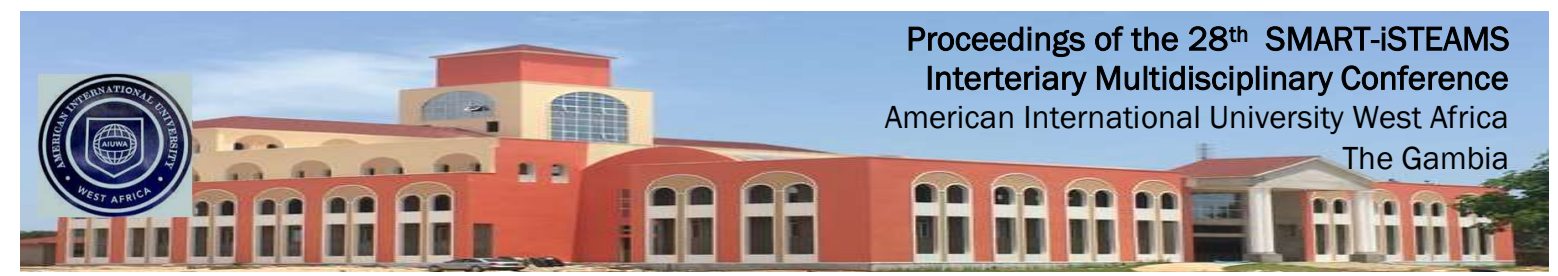

What are the major institutional facilities that affect students' choice of enrolment into public tertiary institution in Lagos Nigeria?

The respondents agreed some major institutional facilities that are available and easily accessible for students use. These facilities are seen as very useful to enhance academic performance and also highly influence their enrolment to the institution. Respondents agreed to campus security come first (91\%) as major institutional factor as available security facilities influenced their choice of enrolment. This is followed by availability of information on institution bill board and website come $88 \%$. Also data gathered shows that knowledge of availability of library facilities and services $85 \%$ comes fifth in the facilities that influence their opinion for enrolment among other facilities.

Table 3: Major institutional facilities that affect students' choice of enrolment into public tertiary institution in Lagos Nigeria

\begin{tabular}{|l|l|l|l|l|}
\hline S/N & INSTITUTIONAL FACILITIES & Agree & Disagree & \\
\hline 1 & Available information on Institutional website & $81 \%$ & $19 \%$ & 5 \\
\hline 2 & Institutions' bill board & $88 \%$ & $22 \%$ & 3 \\
\hline 3 & Sport and sports complex/arena & $75 \%$ & $25 \%$ & 8 \\
\hline 4 & Functional facilities for disable students & $54 \%$ & $46 \%$ & 12 \\
\hline 5 & Campus accommodation & $79 \%$ & $21 \%$ & 7 \\
\hline 6 & Library facilities & $85 \%$ & $15 \%$ & 4 \\
\hline 7 & Free wifi & $76 \%$ & $24 \%$ & 9 \\
\hline 8 & Campus security & $91 \%$ & $09 \%$ & 1 \\
\hline 9 & Safe environment & $90 \%$ & $10 \%$ & 2 \\
\hline 10 & Standard lecture rooms & $80 \%$ & $20 \%$ & 6 \\
\hline 11 & Conducive campus shuttle & $66 \%$ & $34 \%$ & 11 \\
\hline 12 & Students shopping mail/ centre & $68 \%$ & $32 \%$ & 10 \\
\hline
\end{tabular}

What are the effects of institutional facilities on students' choice of enrolment into public tertiary institution in Lagos, Nigeria?

The major institutional facilities do influence students choice of enrolment into tertiary institutions as $x=0.05, P=0.000$; since $P$-value is less than 0.05 (i.e $P<0.05$ ), therefore, the major institutional facilities do affect students choice of enrolment into public tertiary institutions in Lagos, Nigeria. Also, that availability of library facilities and services do have effect on students' choice of enrolment into tertiary institution.

\section{CONCLUSION}

The quest to further education has long being the dreams of all categories of students from high school; thus with the UNESCO 2016 declaration for human right to education brought awareness and increase in students enrolment to tertiary institutions. In addition, students' desire for further education is tailored with the availability of functional facilities as provided by the institution. Though available number of tertiary institutions does not commensurate with the increasing number of students need for admission for further studies, yet students have notion of what they want despite the stringent admission policies to tertiary institutions. 


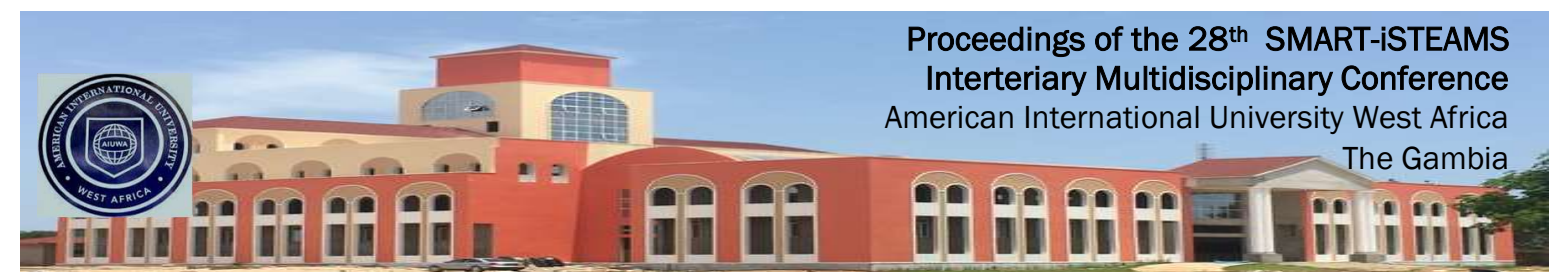

Both the parents and their wards make their choice of admission on the bases of available standard institutional facilities hinge on the image of the institution; such as safety of life and campus security to prevent strike to enable student complete their academic programme in record time.

\section{RECOMMENDATION}

A large percentage of the respondents agreed to the fact that availability and easy accessibility of standard institutional facilities influence their option for enrolment; therefore, it is recommended that academic institutions should invest more on standard facilities to key into UNESCO standard. To this end, tertiary institution must improve on institutional image to entice students' option for enrolment. Also, the management authority of tertiary institutions should see he running of the institution as a business venture in a competitive word and provide a state of art facilities that meet their mission and vision statement to produce graduates that are good ambassador of the institution. All categories of human beings have the right to education, thus the institutional policies for admission should recognise the place for disable candidates. Provisions should be made for convenience of disable students on campus and in the use of available facilities. Tertiary institutions should consider disable students in installing infrastructures; hostel accommodation, walk ways, ramps, library setting and inclusive library services that will enhance disable students' use of the library.

\section{REFERENCES}

1. Abbasi Abdus Sattar and Mir, Ghulam Mustafa (2012). Impact of Teacher's Ability, Student's Work Ethics and Institutional Environment on Student Performance of University of Gujrat Middle-East Journal of Scientific Research 12 (4): 572-579, 2012. Available at SSRN: https://ssrn.com/abstract $=2178577$

2. Ademola, E.O., Ogundipe, A.T. and Babatunde, W.T. (2014) Students' Enrolment into Tertiary Institution in Nigeria: The Influence of the Founder's Reputation - A Case Study Computing, Information Systems, Development Informatics \& Allied Research Journal Vol. 5 No. 3. September 2014 - www.cisdijournal.net

3. Adeyemi, M.A.and Adeyemi, S.B (2014). Institutional Factors as Predictors of Students Academic Achievements in College of Education in South West Nigeria. Journal of Educational Administration and Policy vol. 6(8) Available online http/www.academicjournals.org/IJEAPS

4. Briggs, S and Wilson, A (2007,) 'Which university? A study of the influence of cost and information factors on Scottish undergraduate choice', Journal of Higher Education Policy and Management, vol. 29, no. 1, pp. 57-72.

5. Brown, T. J. et al. (2006), Suggested Terminology, Identity, Intended Image, Construed Image, and Reputation: An Interdisciplinary Framework. Journal of the Academy of Marketing Science,

6. Chery, LIduquette (2000) Experiences at University: Perceptions of students with disabilities The Canadian Journal of Higher Education, Volume XXX, No.2, 2000pages123-142 


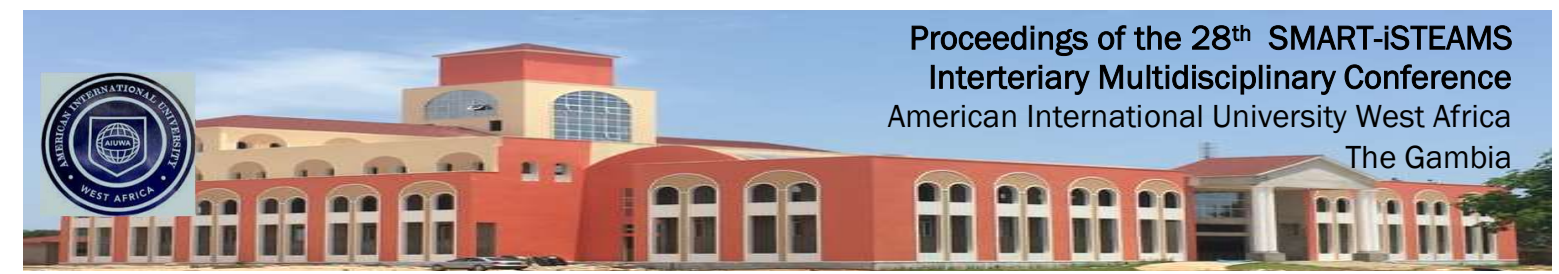

7. Dawes, PL and Brown, J (2002), 'Determinants of awareness, consideration, and choice set size in university choice', Journal of Marketing For Higher Education, vol. 12 , no. 1 , pp. 49- 75.

8. Ekwelem, V.O (2013) Library Services to Disable Students in Digital Era: Challenges for Outcome Assessment. Library Philosophy and Practice Available online http//digitalcommonsUnl.edu/cgi/viewcontent. Cgi?article $=2352 \&$ content $=$ libphilpract

9. Gibbs, P (2001), 'Higher education as a market: A problem or solution?' Studies in Higher Education, vol.26, no. 1, pp. 85

10. Kallio, Ruth E (1995) 'Factors influencing the college choice decisions of graduate students', Research in Higher Education, vol. 36, no. 1, pp. 109-124

11. Kanyip, Bakwaph Peter (2013)."Admission Crisis in Nigeria Universities: The challenges of youth and parents are facing in seeking Admission" Available online http// scholarship. Shu.edu./dissertation/1908

12. Kazoleas, D., Kim, Y. and Moffit, M. A. (2001). Institutional image: a case study. Corporate Communications: An International Journal, 6(4), 205-216. DOI: 10.1108/EUM0000000006148.

13. Kusumawati Andriani (2013). A Qualitative Study of the Factors Influencing Student Choice: The Case of Public University in Indonesia .Journal of Basic and Applied Scientific Research. ISSN 2090-4304 Available online www.textroad.com

14. Louise Moriley and Alison Croft (2011). Agency and Advocacy: disabled students in higher education in Ghana and Tanzania. Research in Comparative and International Education Volume 6 Number 42011 www.wwwords.uk/RCIE

15. Luque-Martínez, T. and Del Barrio-García, S.(2009) Modelling university image: The teaching staff viewpoint. Public Relations Review, In Press, Corrected Proof.

DOI: 10.1016/j.pubrev.2009.03.004

16. Miha Mark, Jasmira Pavlin , Marko Ferjan(2010). Educational Institution's Image: A Case Study.Ogarizacija, vol.3. Doi: 10. 247/u1001-010-007-0

17. Naa Adoley, Alloley (2010). Institutional Factors influencing Students College Choice Decision in Malaysia: A Conceptual Framework. Institutional Journal of Business and Social Sciences Vol 1(3)

18. Ramlee M., Seri B., Saemah R., M. Yusof H., Rahayu A.B. (2014). Environmental Factors and Students' Learning Approaches: A Survey on Malaysian Polytechnics Students. Journal of Education and Learning. Vol.8 (4) pp. 387-398.

19. Rudhumbu, Norman Tirumali Avinash and Kumari, Babli (2017) Factors that influence Undergraduate Students' Chance of a University: A case of Botho University in Botsuwana. In tenational journal of learning and Development

20. UNESCO 2006

21. UNESCO 2016

22. Veloutsou, C, Lewis, JW and Paton, RA 2004, 'University selection: information requirements and importance', The International Journal of Educational Management, vol. 18, no. 2/3, pp. 160-171.

23. Wagner, K and Fard, PY. 2009, "Factors Influencing Malaysian Students' Intention to Study at a Higher Educational Institution." Chinese American Scholars Association, New York, New York, USA, Refereed Program of the E-Leader Conference at Kuala Lumpur, Malaysia, ISSN 1935-4819, Retrieved 11 July, 2009, from http://www.g-cas 